\title{
Teachers’ ICT Skills and ICT Integration in the Classroom: The Case of Vocational and Technical Teachers in Malaysia
}

\author{
Abu-Obaidah Alazam, A. R. Bakar*, R. Hamzah, S. Asmiran \\ Faculty of Educatonal Studies, Universiti Putra Malaysia, 43400 Serdang, Selangor, Malaysia \\ Email: "abrahimbakar@yahoo.com
}

Received 2012

\begin{abstract}
This study was to determine the levels of ICT skills and ICT usage in the classroom among technical and vocational teachers in Malaysia. The data of this study were collected using quantitative techniques, whereby the questionnaire was administered to 329 technical and vocational teachers who were teaching engineering subjects in Malaysian technical and vocational schools. The questionnaire included items related to teachers' ICT skills, ICT use and their demographic factors. The study has shown that teachers' ICT skills were at moderate levels, and that a vast majority of teachers who participated in this study were moderate users of ICT in classroom teaching. There were significant differences of teachers' ICT skills as a function of demographic factors: gender, age, years of teaching experience, and type of ICT training. Also, there were significant correlations between ICT skills and ICT integration in classroom. Teachers' demographic factors (age, gender, teaching experience, except level of education) did not influence ICT integration in classroom.
\end{abstract}

Keywords: Technical and Vocational Education; ICT Skills; Technical and Vocational Teachers; Technical and Vocational Education in Malaysia

\section{Introduction}

The explosion of Information and Communication Technology (ICT) in the last two decades has impacted the life of many people and the nature of jobs in all fields. Education as the main vehicle for human capital development needs to heed to the constant changes in the world of work. In line with the rapid development and usage of ICT in the workplace, it is important that the current generation of students need to well-prepared with ICT knowledge and skills for them to face the tasks in the world-of-work in the future. In fact, ICT is the way of life for the majority of us and we should be fully prepared to live in the ICT world.

Malaysia has a vision called VISION 2020 with the purpose of embracing the knowledge economy in order to become globally competitive. To be able to compete in the globalized world, Malaysia need to develop knowledge workers. Thus, in line with that VISION, The Ministry of Education in Malaysia has recommended the minimum ICT skills that teachers should have in order to lead Malaysian students to compete in the global economy. Countries that are able offer high skilled workforce will be able to attract potential investment in large amount. Technical and vocational education and training (TVET) has the capability of preparing high skilled workforce and the integration of ICT in their classroom will enhance the quality of TVET graduates and will make them the most sought after potential employees. However, in order to integrate ICT in TVET classroom, teachers must have the required skills.

Many studies have been conducted in this country to assess the level of ICT integration in the classroom (Paryono and Quito, 2010; Sukri, 2010; Mahmud and Ismail, 2010; Ngah and Masood, 2006; Wahab and Kaur, 2006; Mustapha, 2000; Bakar

\footnotetext{
Corresponding author.
}

and Mohamad, 1998). These studies report that the level of ICT integration is low or moderate, and the integration of ICT into the classrooms is a dynamic process connecting various factors such as teachers' skills, experience with ICT, gender, age of teacher, level of qualification, type of training, computer and peripheral available at schools, and administration support. These studies assessed the teachers' basic ICT knowledge and skills with the presumption that any teacher of any subject will need to acquire it. Accordingly, the current study examines the level of ICT integration as well as the new ICT skills that the technical and vocational teachers need in teaching engineering subjects specifically in technical and vocational schools in Malaysia.

\section{ICT Skills and Integration}

ICT has become an important component of education of many nations. In some schools ICT is taught as a subject and for the majority ICT is a teaching tool. ICT can do wonders in classroom if used wisely by well-trained teachers. ICT enhances teaching and learning process by increasing students' motivation. The use of ICT in classroom helps in the explanation of difficult concepts so students' are able to easily understand those concepts. The integration of ICT in education can takes several forms such as information and computer networks, digital content, internet sites, multimedia and others. ICT integration can be defined as ICT use in classroom teaching (Lloyd, 2005). ICT integration in technical and vocational classrooms (Kuskaya and Kocak, 2010; Crittenden, 2009) would involve using instructional software during the course, making presentations, carrying out the tasks in laboratories or workshops or application services. However, Lloyd (2005) believed there are conflicting definitions of ICT integration in classroom teaching. To many of us, ICT integration in classroom is using ICT to 
deliver knowledge to students, that means many of us probably do not have a clear understanding about ICT integration in classroom.

Many studies have confirmed the importance of ICT integration in teaching and learning processes in technical and vocational schools. For instance, Crittenden (2009) asserted that the ICT use among technical educators is to transmit, store, create, share or exchange information by various technologies such as radio, television, video, DVD, telephone, satellite systems, computers and the Internet. Few other studies (Jamsek and Kocijancic, 2007; Abdulrasool and Mishra, 2009; Alseddiqi et al., 2009; Bezjak, 2010) indicated that the ICT tools used in the classrooms of technical and vocational schools and in teaching engineering subjects include computer-aided drawing and design (CAD), 2D/3D modeling, simulation products, diagrams, hyperlinked text, video, picture and interactive examples.

Similarly, these studies have pointed out that using ICT in the classroom would motivate students studying engineering and sciences. Previous literatures on teachers' skills and ICT integration in the classroom (Cavas et al., 2009; Tezci, 2009; Drent and Meelisen, 2008; Ngah and Masood 2006) have shown that there are significant positive relationships between teachers' ICT skills and frequency of ICT use. Studies (Agyei and Voogt, 2011; Inan and Lowther, 2010; Culp, 2005) have shown that ICT skills are especially important for effective usage of ICT and are the strongest predictor of technology integration in the classroom.

\section{Purpose of the Study}

The main objective of this study was to describe the levels of ICT skills of technical and vocational teachers in Malaysia and ICT integration in TVET classroom.

To achieve these objectives, the following research questions were developed.

1) What are the levels of ICT skills of technical and vocational teachers?

2) Are there any significant differences in technical and vocational teachers' ICT skills attributed to their demographic factors?

3) To what extent technical and vocational teachers integrate ICT in their classroom teaching?

4) Is there a significant relationship between technical and vocational teachers' integration of ICT in the classroom and their ICT skills?

5) Is there a significant difference of ICT integration as a function of gender, age, teaching experience, and the availability of ICT facilities?

\section{Method}

Data were collected from technical and vocational teachers in Malaysian technical and vocational schools using the survey method.

\section{Population and Sampling}

The target population was the technical and vocational school teachers who were teaching engineering subjects in technical and vocational school. There were 81 technical and vocational schools in Malaysia with 1666 teachers (Data provided on 26 January 2011 by the Department of Technical and Vocational Education (TVE) under the Ministry of Education)

Cochran sampling technique (1977) was used to choose an appropriate sample size from the population. The sample size of 323 teachers was decided. As the number of technical and vocational teachers differed across the schools, the percentage system was adopted so that the results may be accurately calculated. The questionnaires were sent in surplus to each technical and vocational school. In all, 450 questionnaires were sent to compensate for damage or failure in providing responses.

\section{Instrumentation}

The survey instrument was developed in native language (Malay) as well as in English. The instrument comprised three parts (A, B, and C): Part A contained questions about teachers' demographic characteristics, which include gender, age, teaching experience, level of qualification, type of training, and ICT availability. Part B contained questions related to ICT integration into the classroom. Teachers' ICT integration was assessed using 5-point Likert scale (not at all $=1$, seldom $=2$, quite frequent $=3$, frequent $=4$, very frequent $=5$ ). Part $C$, which assess the teachers' ICT skills, was developed based on the following literature: 1) Understanding Computers Today and Tomorrow by Morley and Parker (2009); 2) Computer Graphics by Sourin (2005); 3) Computer Education for Classroom Teaching by Fook et al. (2007); 4) Principles of Multimedia by Parekh (2006); 5) Engineering Drawing and Design by Madsen et al. (2007); 6) AutoCAD 2009 in 3D, A Modern Perspective by Puerta (2009); and 7) A Guide to Programming Languages by Cezzar (1995). In addition, resources of the Department of Education and Training, Western Australia (2006) and Jawarneh et al. (2007) were of also used to develop the instrument. Teachers' skills about software packages (Microsoft Excel, digital video, animation, simulation, CAD), programming languages, and World Wide Web were assessed based on 5-point Likert scale ( $1=$ unskillful, 2 = less skillful, $3=$ moderate skillful, 4 = skillful, and 5 = very skillful).

\section{Validation and Pilot Testing of the Instrument}

To verify the validity of the instrument, the advisory committee, a university professor of technical and vocational education, and a qualified person with vast experience in the field of computer technology have been asked to validate the questionnaire.

The pilot test was carried out using 40 technical and vocational teachers, who were not included in the main study. The internal consistency and reliability of the instrument was estimated using the Cronbach's coefficient alpha. The overall reliability of the instrument was established at 0.97 .

\section{Data Collection and Analysis}

The researcher sent and received the questionnaires through mail. From among 450 questionnaires that were sent out, 329 questionnaires were returned. After the questionnaires were received, the researcher analyzed them using SPSS 18.0 software.

\section{Results}

\section{Demographic Factors}

The number of male respondents were higher (206, 62.6\%) than female respondents $(123,37.4 \%)$. Their age range between 27 and 57 years old with the large percentage (37.1\%) were between 42 - 49 years. For the years of teaching experience, the 
highest percentage was the below 10 years group (105, 31.9\%) followed by 11 - 18 years, 19 - 26 years, and 27 - 34 years. Approximately $80 \%$ of the respondents hold a bachelor degree, $12.2 \%$ hold a diploma, and $8.2 \%$ hold a Master's degree.

Majority of the teachers attended the basic ICT courses (135, $41.0 \%)$ and courses related to Web, multimedia and programming (129, 39.2\%); courses related to ICT integration in teaching and learning process were attended by 33 respondents (10.0\%), while 32 respondents (9.7\%) did not attend any course related to ICT. The respondent ranked ICT availability as 'highly adequate' (62.9\%), 27.7\% ranked it as 'adequate' and $9.4 \%$ ranked it as 'inadequate'.

\section{Teachers' Levels of ICT Skills}

As shown in Table 1, the level of ICT skills among technical and vocational teachers were moderate $(\mathrm{M}=2.42$, S.D. $=0.64)$. The ICT skills consisted of seven groups of skills in this study; the highest mean was for skills of AutoCAD software $(\mathrm{M}=$ 3.25, S.D. = 1.07), followed by skills of World Wide Web $(\mathrm{M}=$ 2.75, S.D. $=0.81$ ), skills of computer-aided design and drafting (CADD) $(M=2.62$, S.D. $=1.02)$, skills of Microsoft Excel $(M$ $=2.48$, S.D. $=0.83)$, skills of digital video and animation $(\mathrm{M}=$ 2.27, S.D. $=0.83)$, skills of programming languages $(\mathrm{M}=1.83$, S.D. $=0.72)$ and skills of simulation $(M=1.77$, S.D. $=0.77)$.

\section{Technical and Vocational Teachers' ICT Skills Attributed to Their Demographic Characteristics}

A one-way analysis of variance was conducted to explore the role of age on levels of ICT skills (Table 2), the impact of teaching experiences on levels of ICT skills (Table 3), and the impact of level of qualification on levels of ICT skills (Table 4) among technical and vocational teachers.

Table 1.

Mean and Standard Deviation for ICT Skills Groups ( $\mathrm{N}=329)$.

\begin{tabular}{lcc}
\hline \multicolumn{1}{c}{ ICT Skills } & Mean & S.D. \\
\hline Microsoft Excel & 2.48 & 0.83 \\
Digital video and animation & 2.27 & 0.83 \\
Simulation & 1.77 & 0.77 \\
AutoCAD software & 3.25 & 1.07 \\
Computer-aided design and drafting & 2.62 & 1.02 \\
Programming languages & 1.83 & 0.72 \\
World Wide Web & 2.75 & 0.81 \\
Total & 2.42 & 0.64 \\
\hline
\end{tabular}

Note: Not skill at all (1); less skillful (2); Moderately skillful (3); Skillful (4); Very skillful (5).

Table 2.

Means and standard deviations by age groups.

\begin{tabular}{cccc}
\hline Age (years) & $\mathrm{N}$ & $\mathrm{M}$ & S.D. \\
\hline Below 33 & 87 & 2.63 & .55 \\
$34-41$ & 84 & 2.35 & .59 \\
$42-49$ & 122 & 2.38 & .69 \\
$\mathbf{5 0 - 5 7}$ & $\mathbf{3 6}$ & $\mathbf{2 . 2 3}$ & $\mathbf{. 6 4}$
\end{tabular}

$\mathrm{F}(3,325)=4.691, \mathrm{p}<.05$.
Table 3.

Means and standard deviations by teaching experience.

\begin{tabular}{lccc}
\hline \multicolumn{1}{c}{ Teaching experiences (years) } & $\mathrm{N}$ & $\mathrm{M}$ & S.D. \\
\hline Below 10 & 105 & 2.63 & .56 \\
$11-18$ & 101 & 2.30 & .61 \\
$19-26$ & 87 & 2.39 & .70 \\
$27-34$ & 36 & 2.27 & .63 \\
\hline
\end{tabular}

$\mathrm{F}(3,325)=5.946, \mathrm{p}<.05$.

Table 4.

Means and standard deviations of ICT skills by qualification.

\begin{tabular}{cccc}
\hline Level of qualification & $\mathrm{N}$ & $M$ & S.D. \\
\hline Diploma & 40 & 2.30 & .57 \\
Bachelor & 262 & 2.42 & .64 \\
Master & 27 & 2.66 & .64 \\
\hline
\end{tabular}

$\mathrm{F}(2,326)=2.576, \mathrm{p}>.05$.

As shown in Table 2, subjects were divided into four groups based to their age (Group 1: below 33; Group 2: 34 to 41; Group 3: 42 to 49; Group 4: 50 to 57). There was a statistically significant level of ICT skill among the four groups: F $(3,325)$ $=4.691, \mathrm{p}=.003$. The effect size, calculated using eta squared, was 0.05, which in Cohen's (1998) terms would be considered a small effect size.

Teachers' teaching experiences were divided into four categories: below 10 years; 11 to 18 years; 19 to 26 years; 27 to 34 years). There was a statistically significant different of ICT skill among the four groups: $F(3,325)=5.95, p=.001$. The effect size, calculated using eta squared, was 0.03 , which in Cohen's (1998) terms would be considered a small effect size.

The impact of level of qualification on levels of ICT skills (Table 4) was analyzed using One-way ANOVA. Teachers were divided into three groups according to their level of qualification (diploma, bachelors and masters). There was no statistically significant difference at $\mathrm{p}>.05$ level in ICT skill scores for the four groups: $\mathrm{F}(2,326)=2.579, \mathrm{p}=.077$. The effect size, calculated using eta squared, was 0.02, which in Cohen's (1998) terms would be considered a small effect size.

An independent sample T-test was conducted to compare the ICT skills for male and female teachers (Table 5). There was a significant difference ICT skill levels between males $(\mathrm{M}=2.50$; S.D. $=0.68)$ and females $(\mathrm{M}=2.29$; S.D. $=0.53)$; $\mathrm{t}(327)=$ $2.91, \mathrm{p}=<.004$. Four categories of ICT skills were found to be significantly different between male and female respondents. Those skills were: Microsoft excel with $\mathrm{p}=<.03$, digital video and animation with $\mathrm{p}=<.04$, AutoCAD with $\mathrm{p}=<.01$, and CAD with $p=<.00$. This magnitude of differences in the means (eta squared $=0.10$ ), in Cohen's (1998) terms, would be considered a large effect size.

A one-way analysis of variance was performed to discover the difference of ICT skills as a function of type of training (basic ICT course, related to ICT integration in teaching and learning process, related to Web, multimedia and programming languages, did not attend any course) and the available of ICT facilities in schools on levels of ICT skills among teachers. There was a statistically significant difference at $\mathrm{p}<.05$ level in ICT skill scores as a function of types of training attended 


\section{A.-O. ALAZAM ET AL.}

Table 5.

Results of t-test on the differences of ICT skills as a function of gender.

\begin{tabular}{|c|c|c|c|c|c|c|c|}
\hline ICT skills & Gender & $\mathrm{N}$ & M & S.D. & $\mathrm{df}$ & $\mathrm{t}$ & $\mathrm{p}$ \\
\hline & Male & 206 & 2.56 & .86 & & & \\
\hline \multirow[t]{3}{*}{ Microsoft Excel } & & & & & 327 & 2.179 & $<030$ \\
\hline & Female & 123 & 2.36 & .75 & & & \\
\hline & Male & 206 & 2.34 & .89 & & & \\
\hline \multirow[t]{3}{*}{ Digital video and animation } & & & & & 327 & 2.078 & $<.038$ \\
\hline & Female & 123 & 2.14 & .70 & & & \\
\hline & Male & 206 & 1.81 & .81 & & & \\
\hline \multirow[t]{3}{*}{ Simulation } & & & & & 327 & 1.234 & .218 \\
\hline & Female & 123 & 1.70 & .71 & & & \\
\hline & Male & 206 & 3.36 & 1.09 & & & \\
\hline \multirow[t]{3}{*}{ AutoCAD } & & & & & 327 & 2.497 & $<.013$ \\
\hline & Female & 123 & 3.06 & 1.03 & & & \\
\hline & Male & 206 & 2.78 & 1.07 & & & \\
\hline \multirow[t]{3}{*}{ CAD } & & & & & 327 & 3.755 & $<.000$ \\
\hline & Female & 123 & 2.35 & .85 & & & \\
\hline & Male & 206 & 1.87 & .77 & & & \\
\hline \multirow[t]{3}{*}{ Programming languages } & & & & & 327 & 1.518 & .130 \\
\hline & Female & 123 & 1.75 & .63 & & & \\
\hline & Male & 206 & 2.79 & .84 & & & \\
\hline \multirow[t]{3}{*}{ World Wide Web } & & & & & 327 & 1.000 & .318 \\
\hline & Female & 123 & 2.70 & .74 & & & \\
\hline & Male & 206 & 2.50 & .68 & & & \\
\hline \multirow[t]{2}{*}{ Overall ICT skills } & & & & & 327 & 2.91 & $<.004$ \\
\hline & Female & 123 & 2.29 & .53 & & & \\
\hline
\end{tabular}

$\left(F_{(3,325)}=3.324, p=.020\right)$. The effect size, calculated using eta squared, was 0.03, which in Cohen's (1998) terms would be considered a small effect size. Those attended training related to Web, multimedia and programming languages obtained a significantly higher mean scores than others (Table 6)

The availability of ICT facilities in school is divided into inadequate, adequate and highly adequate. Based on one-way ANOVA, no statistically significant difference of ICT skills among teachers was found based on the availability of ICT facilities $\left(\mathrm{F}_{(2,326)}=1.007, \mathrm{p}=.367\right.$. The effect size, calculated using eta squared, was 0.02, which in Cohen's (1998) terms would be considered a small effect size.(Table 7)

Table 6.

Means and standard deviations of ICT skills by types of training.

\begin{tabular}{lccc}
\hline Type of training & $\mathrm{N}$ & $\mathrm{M}$ & $\mathrm{S} . \mathrm{D}$. \\
\hline Basic ICT course & 135 & 2.36 & .60 \\
$\begin{array}{l}\text { Related to ICT integration in teaching } \\
\text { and learning process }\end{array}$ & 33 & 2.31 & .68 \\
$\begin{array}{l}\text { Related to Web, multimedia and } \\
\text { programming languages }\end{array}$ & 129 & 2.56 & .61 \\
\begin{tabular}{l} 
I did not attending course \\
\hline
\end{tabular} & 32 & 2.27 & .77 \\
\hline
\end{tabular}

$\mathrm{F}(3,325)=3.24, \mathrm{p}<.05$.
Table 8 shows the levels of ICT usage in the classroom. It showed that $36.8 \%$ of respondents frequently used ICT in the classroom, $0.6 \%$ of teachers did not use ICT at all in the classroom, 33.1\% of teachers quite frequently used ICT in the classroom, $21.6 \%$ of teachers seldom used ICT in the classroom, and $7.9 \%$ of teachers very frequently used the ICT in the classroom. The study shows that almost $70 \%$ of the respondents used ICT in the classroom at a moderate level.

Table 7.

Means and standard deviations of ICT skills by the availability of ICT facilities.

\begin{tabular}{lccc}
\hline ICT availability & $\mathrm{N}$ & $\mathrm{M}$ & S.D. \\
\hline Inadequate & 31 & 2.53 & .56 \\
Adequate & 91 & 2.36 & .72 \\
Highly adequate & 207 & 2.44 & .60 \\
\hline
\end{tabular}

$\mathrm{F}(2,326)=1.007, \mathrm{p}>.05$

Table 8.

Levels of ICT Usage in the Classroom.

\begin{tabular}{lcc}
\hline & $\mathrm{F}$ & $\%$ \\
\hline Not at all & 2 & .6 \\
Seldom & 71 & 21.6 \\
Quite frequently & 109 & 33.1 \\
Frequently & 121 & 36.8 \\
Very frequently & 26 & 7.9 \\
\hline
\end{tabular}


We conducted a chi-square analysis (Table 9) to determine if ICT integration is dependent on selected demographic variables (gender, age, teaching experience, level of qualification, ICT availability in school). Of these variables, only one variable, that is, level of qualification appeared to have some influence on the ICT integration in classroom $\left(\mathrm{X}^{2}(8)=24.24, \mathrm{p}=0.01\right)$. Only those with a bachelor degree tend to integrate ICT more frequently than the others.

\section{Discussion}

In respect of the research question number one as to the level of ICT skills among technical and vocational teachers in Malaysia, this study found that ICT skills among technical and vocational teachers was moderate $(\mathrm{M}=2.42$, S.D. $=0.64)$. The skills of AutoCAD software were at a high level $(\mathrm{M}=3.25$, S.D. $=1.07)$, and the skills of programming languages $(\mathrm{M}=1.83$, S.D. $=0.72)$ and simulation $(\mathrm{M}=1.77$, S.D. $=0.77)$ were at a low level. The data derived from teachers' questionnaire indicate that a vast majority of the teachers participating in this study have a moderate level of ICT skills for all seven categories of ICT skills were at moderate levels. The respondents were found to be skillful in one particular category of skills, AutoCAD skills. They had the lowest level in one category of skills, that is, simulation skills.

Literature has highlighted the importance of ICT skills for teachers for a greater integration of ICT into technical and vocational education (Buntat et al., 2010; Paryono and Quito, 2010; Sukri, 2010; Usman and Pascal, 2009; Kumar et al., 2008). Related tudies have shown that different skills and techniques needed to teach engineering subjects in technical and vocational schools; these skills include CADD, AutoCAD, animation, video clips with multimedia, and simulation (Abdulrasool and Mishra, 2009; Alseddiqi et al., 2009; Jamsek and Kocijaancic, 2007). The findings of this study about teachers' ICT skills are in congruence with previous studies. In this study, a vast of majority of technical and vocational teachers possessed moderate levels of ICT skills. These results are consistent with other published studies (Mahmud and Ismail, 2010; Rosnaini, 2006; Bakar and Mohamed, 1998).

With respect to the research question number two as to whether there were significant differences between teachers' ICT skills and their demographic factors, the findings of this study showed significant differences between teachers' ICT skills and gender. These results are in agreement with other studies (Jowarneh et al., 2007; Sharif and Osman, 2005). Surprisingly, although all teachers have equal opportunity to sit in the training programs organized by MOE, the results indicate that male teachers have higher levels of ICT skills than female teachers, and these results are in contrast to other studies. In a study by Jowarneh et al. (2007) of vocational teachers, it was found that female teachers have higher levels of ICT skills compared to male teachers.

Table 9.

ICT integration as a function of gender, age, experience, and facilities.

\begin{tabular}{llc}
\hline Variable & Test & $\mathrm{p}$ \\
\hline Gender & $\mathrm{X}^{2}(4)=9.58$ & 0.05 \\
Age & $\mathrm{X}^{2}(12)=17.65$ & 0.13 \\
Teaching experience & $\mathrm{X}^{2}(12)=23.25$ & 0.26 \\
Level of qualification & $\mathrm{X}^{2}(8)=24.24$ & 0.01 \\
ICT availability & $\mathrm{X}^{2}(8)=3.31$ & 0.91 \\
Training & $\mathrm{X}^{2}(12)=9.06$ & 0.69 \\
\hline
\end{tabular}

The present study also found significant differences of teachers' ICT skills as a function of their age and years of teaching experience, in that younger teachers had higher ICT skills than others. These findings are in congruence with other studies (Kotrlik and Smith, 1989; Department of Education and Training, 2006; Lau and Sim, 2008) that reported that teachers' age has statistically significance with ICT skill scores and that younger teachers have higher levels of ICT skills. Moreover, those with fewer years of teaching experience are the ones with higher levels of ICT skills than those with more years of teaching experience.

Regarding the effect of type of training on teacher's ICT skills, there were significant differences between ICT skills and type of training at the 0.05 level of significance. These results are in agreement with other studies (Mahmud and Ismail, 2010; Ozden, 2007), which also indicate that teachers lacking ICT skills is due to lack of pre-service and in-service training. Moreover, the results of this study showed that the teachers who did not attend any ICT course had lower ICT skill scores than those who attended ICT courses. As shown in Table 6, the highest scores were for teachers who attended training related to Web, multimedia and programming languages. Notably, these are part of the training curriculum of MOE.

With respect to the influence of ICT availability and level of qualification on teachers' ICT skills, there were no significant differences at the 0.05 level of significance. These results are not consistent with other studies (Oqunkola, 2008; Kumar et al., 2008; Wozney et al., 2006), which indicated that ICT availability influenced teacher's ICT skills significantly. The difference in the findings may be attributed to the presence of adequate ICT resources in schools that participated in this study. The teachers have had greater opportunities to enhance their ICT skills with ICT resources available in their schools. We also tested if there was a significant relationship between technical and vocational teachers' level of ICT use in the classroom and their ICT skills, the findings of this study indicated that there was a significant and positive correlation between teachers' ICT skills and ICT use in the classroom. These results are in agreement with few other studies (Drent and Meelisen, 2008; Tezci, 2009; Agyei and Voogt, 2011). However, this finding is in contradiction with a study by Kumar et al. (2008) that explored teachers' readiness to use computers in secondary schools in Malaysia. They found that there were no significant linear relationship between teachers' ability and skills about using software and their actual use of computers. A chi-square analysis to determine if ICT integration is dependent on selected demographic variables (gender, age, teaching experience, level of qualification, ICT availability in school) showed that, of these variables, only one variable, that is, level of qualification appeared to have some influence on the ICT integration in classroom $\left(X^{2}(8)=24.24, p=0.01\right)$. Only those with a bachelor degree tend to integrate ICT more frequently than the others.

\section{Conclusion}

This study examines the levels of ICT skills and ICT use in the classrooms among technical and vocational teachers in Malaysia. The findings indicated that the level of teachers' ICT skills was moderate, and the skills of AutoCAD software were at a high level and the skills of programming languages and simulation were at low level. Furthermore, there were signifi- 
cant differences between teachers' ICT skills and their gender, age, years of teaching experience and type of ICT training, but not with levels of qualification and ICT availability. In addition, a vast majority of teachers who participated in this study were frequent users of ICT in classroom teaching. However, the study reveals that they 'quite frequently use' and 'frequently use' ICT in classroom (70\%) with only $8 \%$ heavy users. As ICT is an important tool in education, teachers should be using ICT very frequently in their teaching.

We need to increase the level of ICT usage in classroom. Based on this present study, ICT usage in vocational and technical classroom is at a moderate level only. The level of ICT usage in classroom may be attributed to the skills they have. As shown by the study, there was a significant correlation between ICT use in the classroom and teachers' ICT skills. But, it was also discovered that the respondents' ICT skills were not very high. If it is true as found, some serious actions have to be taken to ensure that teachers do have the skills needed for them to integrate ICT I teaching vocational and technical subjects. The study also showed that there were significant differences between teachers' ICT skills and their gender, age, years of teaching experience and type of ICT training, however it is not reflected in ICT integration. In fact the study showed that ICT training do influence ICT skills acquisition by teachers, whereby those teachers who attended training obtained a significantly higher ICT skills those who did not attend the training, but based on chi-square analysis, attending ICT training has no influence on ICT integration. This is something we need to ponder. They have been trained in some ICT course and they have skills, yet they do not integrate ICT in their teaching. The relevant authority needs to find reasons as to why the ICT integration in vocational and technical classroom is low.

\section{REFERENCES}

Abdulrasool, S. M. \& Mishra, R. (2009). Using Computer Technology Tools to Improve the Teaching-Learning Process in Technical and Vocational Education: Mechanical Engineering Subject Area. International Journal of Learning, 15 (12), 155-168.

Abdullah, N. A., Abidin, M. J. Z., Wong, S. L., Majid, O. \& Atan. (2006). The Attitude and Motivation of English Language Teachers towards the Use of Computers. Malaysian Online Journal of Instructional Technology (MOJIT), 3(1), 57-67.

Agyei, D. D \& Voogt, J. M. (2011). Exploring the potential of the will, skill, tool model in Ghana: Predicting prospective and practicing teachers' use of technology. Computer \& Education, 56 (1), 91-100.

Albion, P. (2000). Setting course for the new millennium: Planning for ICT in a New Bachelor Degree Program. In Society for Information Technology and Teacher Education International Conference, San Diego: California, February 8-12, 2000, 1-3, IR 020 112, retrieved from database (ED 444 499).

Alseddiqi, M., Mishra, R \& Abulrasool, S. M. (2009). Improving teaching and learning effectiveness in engineering education. The International Journal of Learning, 17(9), 11-26.

Bakar, R., \& Mohamed, S. (1998). Preparing Malaysian vocational and technology teachers to integrate computer technology in teaching vocational and technology subjects. Computers and Education, 31(4), 365-372.

Bezjak, J. (2010). Contemporary engineer pedagogic's project research - using multimedia at technology classes in technical and vocational school. Procedia Social and Behavioral Sciences , 2 (2), 407-411.

Buntat, Y., Saud, M. S., Dahar, A., Arifin, K. S \& Zaid, Y. H. (2010). Computer technology application and vocational education: A review of literature and research. European Journal of Social Sciences, 14(4), 645-651.
Cavas, B., Cavas, P., Karaoglan, B., \& Kisla, T. (2009). A study on science teachers' attitudes toward information and communication technologies in education. The Turkish Online Journal of Educational Technology - TOJET, 8(2), 20-32.

Cezzar, R. (1995). A Guide to Programming Languages. Norwood, MA: Artech House, INC.

Crittenden, J. C. (2009). The attitudes and perceived self-efficacy of Mississippi career and technical educators toward information and communication technology. Unpublished Doctoral Dissertation, Mississippi State University.

Cochran, W.G. (1977). Sampling Techniques (3rd ed.). New York: John Wiley \& Sons.

Department of Education and Training, Western Australia. (2006). Evaluation of the Information and Communication Technology (ICT) Knowledge and Skills Levels of Western Australian Government School Teachers. From:

http://www.det.wa.edu.au/education/accountability/docs/ict\%20repor t\%20final.pdf

Drent, M. \& Meelissen, M. (2008). Which factors obstruct or stimulate teacher educators to use ICT innovatively? Computers and Education. 551(1), 187-199.

Evoh, C. J. (2007). ICTs, secondary education, and the knowledge economy: Exploring the roles of the private sector in Post-Apartheid South Africa. Journal of Education for International Development, 3 (1), 1-25.

Fook, C. Y., Sidhu, R. K., Baba, J \& Parman, E. (2007). Computer education for classroom teaching. Malaysia. McGraw-Hill.

Radiman, N. \& Abdullah, R. (2010). ICT integration in vocational and technical education and training institutions in Brunei Darussalam. Presentation in An International Conference on VTET Research and Networking. SEAMO VOCTECH Regional Centre, Brunei Darussalam. From: http://www.voctech.org.bn/conference/presentations/[BN]\%20Norly \%20\&\%20Rahmah.pdf

Inan, I. A \& Lowther, D. L. (2010). Laptops in the K-12 classrooms: Exploring factors impacting instructional use, Computer \& Education, 55 (3), 937-944.

Jamsek, J \& Kocijancic, S. (2007). Computer based laboratory course "From Electricity to Electronics". ComLab Conference, 2007. From: ttp://e-prolab.com/en/conf/papers_pdf/janez.pdf

Jawarneh, T., El-hersh, A., \& Khazaleh, T. (2007). Vocational education teachers'adoption of information and communications technology (ICT) in Jordanian secondary vocational schools. Journal of Educational \& Social Sciences \& Humanities, 19 (02), 11-56.

Kanaya, T., Light, D., \& Culp, K. M. (2005). Factors influencing ou tcomes from a technology-focused professional development program. Journal of Research on Technology in Education, 37(2), 313-329.

Kotrlik, J. W., \& Smith, M. N. (1989). Computer anxiety levels of vocational agriculture teachers. Journal of Agricultural Education, 30 (2), 41-48.

Kuskaya, F. M., \& Kocak, Y. U. (2010). ICT in vocational and technical schools: teachers' instructional, managerial and personal use matters, TOJET: The Turkish Online Journal of Educational Technology, 9(1), 107-113.

Kumar, N., Rose, R. C., \& D’Silva, J. L. (2008). Predictors of Technology Deployment Among Malaysian Teachers. American Journal of Applied Sciences, 5 (9), 1127-1134.

Lau, B., \& Sim, C. (2008). Exploring the Extent of ICT Adoption Among Secondary School Teachers In Malaysia. International Journal of Computing and ICT Research, 2 (2), 19-36.

Lloyd, M (2005). Towards a definition of the integration of ICT in the classroom. In AARE 2005, AARE, Eds. Proceedings AARE '05 Education Research - Creative Dissent: Constructive Solutions, Parramatta, New South Wales. From: http://eprints.qut.edu.au/3553/1/3553.pdf.

Madsen, A., Madsen, P \& Turpin, J. (2007). Engineering Drawing and Design ( $4^{\text {th }}$. ed.). Thomson Delmar Learning.

Mahmud, R. \& Ismail, M.A. (2010). Impact of Training and Experience in Using ICT on In-Service Teachers' Basic ICT Literacy. Malaysian Journal of Educational Technology, 10(2), 5-10.

Mc Millan, J.H. dan Shumacker, S. (1984). Research in Education: A 
Conceptual Introduction. Canada: Little Brown Co.

Morley, D \& Parker, C. (2009). Understanding Computers Today and Tomorrow (12 $2^{\text {th }}$ ed.). Boston, MA: Course Technology, Cengage Learning.

Mustapha, R. B. (2008) IT and Multimedia in Technical and Vocational Education in Malaysia. Paper presented at the IVETA (International Vocational Education and Training Association) Conference Hong Kong, August 6-9, 2000. Retrieved from ERIC database (ED 447 311).

Ngah, N. A., \& Masood, M. (2006). "Development of ICT instructional Materials Based on Needs Identifed by Malaysia Secondary School Teachers" (proceedings of the 2006 Informing Science and IT Education Joint Conference, Greater Manchester, England, June 25-28, 2006).

http://informingscience.org/proceedings/InSITE2006/ProcNgah164.p df

Ogunkola, J. B. (2008). Computer Attitude, Ownership and Use as Predictors of Computer Literacy of Science Teachers in Nigeria. International Journal of Environmental \& Science Education, 3(2), 53 $-57$.

Ozden, M. (2007). Problems with science and technology education in Turkey. Eurasia Journal of Mathematics, Science \& Technology Education, 3(2), 157-161.

Parekh, R. (2006). Principle of Multimedia. New Delhi: McGraw-Hill.

Paryono \& Quito, B. G. (2010). Meta-analysis of ICT integration in vocational and technical education in Southeast Asia. An International Conference on VTET Research and Networking. SEAVERN Research Report. SEAMO VOCTECH Regional Centre, Brunei Darussalam. From: http://www.voctech.org.bn/conference/papers/[VOCTECH]\%20Pary ono\%20\&\%20Ben.pdf

Puerta, F. E. (2009). AutoCAD 2009 in 3D. A modern perspective. New
Jersey: Prentice Hall.

Rosnaini Mahmud. (2006). ICT readiness of secondary school teachers. Unpublished Doctoral Dissertation, Universiti Kebangsaan Malaysia.

Sharif, S. \& Osman, K. (2005).Teacher's perception on professional development needs in information and communication technology (ICT). Inovasi Teknologi Instruksional dalam Pengajaran dan Pembelajaran: Konvensyen Teknologi Pendidikan ke-18 (pp. 446-454). Terengganu: Persatuan Teknologi Pendidikan Malaysia.

Sourin, A. (2005). Computer Graphics. Singapore: Prentice Hall.

Sukri, M. S.et al. (2010). ICT application in vocational and technical education and training (VTET) institutions in Malaysia. An International Conference on VTET Research and Networking. SEAVERN Research Report. SEAMO VOCTECH Regional Centre, Brunei Darussalam.

From: http://www.voctech.org.bn/conference/papers/[MY]\%20Dr.\%20Sukr i\%20Saud\%20\&\%20Prof.\%20Rashid.pdf

Tezci, E. (2009). Teachers' effect on ICT use in education: the turkey sample. Procedia Social and Behavioral Sciences, 1 (1) 1285-1294.

Usman, A. A., \& Pascal, G. (2009). The role of Technical and Vocational Education and Training (TVET) in Human Resources Development: the case of Tumba College of Technology (TCT)-Rwanda. From: http://www.tct.ac.rw/images/Ayuba.pdf

Wahab, B. M., \& Kaur, K. (2006). Towards a better understanding of the need for a digital school resource center in Malaysian smart schools. In Prosiding Konvensyen Persatuan Teknologi Pendidikan Malaysia ke 19, 16-19 September 2006. From: http://eprints.um.edu.my/295/

Wozney L., Venkatesh V \& Abrami P. (2006). Implementing computer technologies: Teachers' perception and practices. Journal of Technology and Teacher Education, 14, 173-207. 